\title{
Valuing Riparian Forests Restoration: a CVM Application in Corumbatai River Basin
}

\author{
Caetano Brugnaro
}

\begin{abstract}
This study is an application of CVM to a specific area in Brazil, the Corumbatai river basin, in the state of Sao Paulo, aiming to estimate the value attached by affected people to a hypothetical riparian forest restoration project. The method used was the double bounded dichotomous choice under a logit model. Data were obtained by street-intercept interviews with a net sample of 930 individuals, 20 years or older, living in seven municipalities (cities and respective rural areas) that contain the basin. Protest bid responses were not excluded in a first approximation, resulting in a $\mathrm{R} \$ 2.06$ mean willingness to pay (WTP) for the riparian forest restoration, equivalent to approximately $\mathrm{R} \$ 274,000$ per month ( $\mathrm{R} \$ 1.00$ equivalent to US\$ 0.52 at the survey period) when accounting for about 133,000 residences in the area. It was observed an expressive number of "no-no" responses from people ascribing the problem to government and farmers and suspecting on misuse of funds by the official agencies involved.
\end{abstract}

Key-words: contingent valuation; willingness to pay; riparian forest valuation; environmental value.

Resumo: Para este estudo, foi aplicado o CVM (Contingent Valuation Method) a uma área específica do Brasil, a bacia do rio Corumbataí, no estado de São Paulo, visando estimar o valor atribuído pela população afetada a um hipotético projeto de reposição de matas ciliares. O método utilizado foi o de escolha dicotômica com limite duplo, sob o modelo da distribuição logística. Os dados foram obtidos por meio de entrevistas nas ruas, numa amostra líquida de 930 pessoas com 20 anos ou mais, moradoras de sete municípios que englobam a bacia. Numa primeira aproximação, não se excluíram as manifestações de protesto, resultando em $R$ \$2,06 como valor médio da disposição a pagar pela reposição de matas ciliares, o que equivale a aproximadamente $R \$ 274$ mil por mês,

1 Professor Associado, UFSCar. E-mail: caetanob@terra.com.br 
quando computadas as aproximadamente 133 mil residências na área. Observou-se um grande número de respostas "não-não" de pessoas que atribuem o problema ao governo e agricultores e que suspeitam do mau uso dos recursos pelas agências envolvidas.

Palavras-chave: valoração contingente, disposição a pagar, valoração de matas ciliares, valor do ambiente.

Classificação JEL: Q51, Q57.

\section{Introduction}

The main environmental services supplied by riparian natural vegetation is a well studied matter. The so-called buffer zones function as a filter for agricultural wastes carried by run-off and groundwater such as soil from erosion, organic matter and chemical residues which decrease the water quality. The riparian vegetation also provides other services such as feed for fishes and other aquatic forms of life, some water temperature regulation, habitat for wildlife, biodiversity as well as scientific, cultural and aesthetic utilities.

Cost-benefit analysis of preservation and increase in the area covered by riparian forests, under the neoclassical theory, face a strong limitation: environmental services are usually non-market goods, with no indicator of their values represented by market prices. Many authors consider them public goods because they are neither divisible nor exclusive and rival in consumption, as required by market goods. In fact, these environmental services are externalities, mainly generated by agricultural activities. This makes evaluation of real costs and benefits a burdensome if not an impossible task. A disagreement between farmers and the rest of society arises when the consequences of deforestation become more visible: the farmer want more agricultural land and the latter higher environmental quality levels. Because there are no safety methods to establish the ideal level, solutions are typically political (BROMLEY, 1996).

Some methods were developed to estimate the social welfare value from the preservation or increase in environmental services. Many of these methods are based on the assumption of the existence of a demand function for these services so that each individual has her/his own willingness to pay (WTP) for some amount of environmental quality. On the other hand, those who are willing to give up some amount of environmental quality only do so if they receive some compensation for it (willingness to accept - WTA); see, among others, Bishop \& Heberlein (1979); Cummings et al. (1986); Mitchell \& Carson (1989); Pearce \& Turner (1989); Randall (1997). Although numerous articles and books have been published on the subject, mainly in the last two decades, very few are about developing countries like Brazil and to this author's knowledge, no focused on riparian forest restoration. This is the objective of this study: 
to estimate the value of riparian forests restoration in the Corumbatai basin, located in the state of São Paulo, Brazil.

The basin area is located between the coordinates $22^{\circ} 05^{\prime} \mathrm{S}, 22^{\circ}-30^{\prime} \mathrm{S}, 47^{\circ}-30^{\prime} \mathrm{WG}$ and 47-50'WG, covering 1710 square kilometers (KOFFLER, 1993), contained by seven municipalities, with a population of approximately half million people living in about 133,000 residences (SEADE, 1999).

There are 4,600 farms in the watershed, averaging $55.5 \mathrm{ha}, 89.5 \%$ of which with 100 hectares or less. Their main uses of land are pasture $(39.7 \%)$ and sugarcane $(35.2 \%), 7.2 \%$ of total area are covered by natural vegetation (PINO et al., 1997). Approximately 11,500 hectares are classified as riparian areas needing reforestation (NASSIF \& VIANA, 1998).

Household heads have, on average, 6.5 years of formal education and around 90\% have annual income below R\$ 16,320 at December 1999 prices (SEADE, 1999).

All urban water need is supplied by surface or ground Corumbatai basin, highlighting the importance of its quality for the people living in the study area.

The so-called Forestry Code (BRASIL, 1965) establishes the rules on preservation of natural vegetation. According to it, riparian forests are to be permanently preserved in stripes along each side of the river whose width depends directly on watercourse width (Table 1). The Forestry Code was later amended with other regulations such as farmers' obligation to restore the natural vegetation where it must be preserved but it was depleted even before the approval of this specific law (BRASIL, 1989). These and other legal documents establish the penalties incurred by law breakers.

Table 1. Watercourse and legal riparian forests width.

\begin{tabular}{cc}
\hline River width $(\mathbf{m})$ & Riparian forest width $(\mathbf{m})$ \\
\hline$<10$ & 30 \\
10 to 50 & 50 \\
50 to 200 & 100 \\
200 to 600 & 200 \\
$>600$ & 500 \\
\hline
\end{tabular}

Source: Brasil (1965).

Despite regulations, property rights have not been enforced probably due to the high transaction costs involved, low penalties applied to law breakers, or strong farmers' economic and political power. The result is a continuous decrease in the area under natural vegetation in general and under riparian forests in particular, leading to a forested area far below what is established by law.

However, the increasing population's awareness of the importance of the environmental quality is stimulating initiatives from public agencies and non- 
governmental organizations. But they are sparse projects, not part of global program. Besides, these projects aiming riparian forest restoration usually take place without a formal social agreement. In fact, Brazilian policies such as increases in public services, production and/or consumption taxes as a way of funding such projects are frequently adopted in the absence of formalized population referenda. Presently, the Brazilian Federal Congress discusses the charge of $\mathrm{R} \$ 0.01$ per cubic meter of consumed water in order to finance project on water quality improvement, including riparian forests restoration.

Since Samuelson (1954), the consumption of public goods has been included as an argument in the individual utility function. Referring to market goods, Willig (1976) established the upper and lower bounds of the non observable hicksian welfare change measures, compensated and equivalent variations due to a single price change, based on the observable consumer surplus. Randall \& Stoll (1980) built a model that predicts welfare changes due to a variation in the quantity supplied of a good, not necessarily with changes in income and prices. The application of their conclusion to public goods, however, depends upon a crucial assumption: the existence of a demand function for these goods so that it is possible to estimate the individual WTP to consume a certain amount of it.

The methods to elicit the individual WTP - and, by aggregation, the mean, median and total value - are indirect or direct depending on the nature of the service. If the good is perfectly divisible, exclusive, rival, with at least one perfect substitute, the model states $W T P=W T A=M$, where $M$ is the marshallian consumer surplus (FREEMAN, 1979; RANDALL, 1987; HANEMANN, 1991; BROWN, 1994; BROWN \& GREGORY, 1999). If the service is a non-market good and if it has no associated market goods and the objective is to estimate the total value, including use and non-use values, the only method largely accepted is the Contingent Valuation Method (CVM). In this case, if the project focus on individual's response to an increase in the supply service, WTP, rather than WTA, seems to be the appropriate measure to be used.

\section{The model}

Hanemann's model $(1984 ; 1989)$ on utility differences was used as the basis to estimate the WTP for riparian forest restoration in the studied area. According to Hanemann, the individual is willing to pay $b$ for the increase $\Delta q$ in the environmental service if

$$
v(d, r-b \mid \mathbf{s})+\varepsilon_{1}>v(d, r \mid \mathbf{s})+\varepsilon_{0}
$$

where $v($.$) is the individual indirect utility function, d=1$ if the project is implemented and $d=0$ otherwise, $r$ is her/his income level, $\mathbf{s}$ is a vector of the individual's socioeconomic characteristics and $\varepsilon$ the disturbance term. Asking the individual about her/his WTP the 
amount $b$ for consuming $\Delta q$, the probability $\pi^{y}=\operatorname{prob}\{d=1\}$ of a positive response ("yes") is

$$
\pi^{y}=\operatorname{prob}\left\{v(1, r-b \mid \mathbf{s})+\varepsilon_{1}>v(0, r \mid \mathbf{s})+\varepsilon_{0}\right\}
$$

and obviously the probability $\pi^{n}=\operatorname{prob}\{d=0\}$ of a "no" response is $\pi^{n}=1-\pi^{y}$.

If the errors $\varepsilon_{0}$ and $\varepsilon_{1}$ are i.i.d. random variables, one can write

$$
\pi^{y}=F_{\varepsilon}(\Delta v)
$$

where $F$ is a c.d.f. for $\varepsilon$ and $\Delta v=v(1, r-b \mid \mathbf{s})-v(0, r \mid \mathbf{s})$.

One of the measures suggested by Hanemann and modified in order to allow for reduction in the individual's utility level as a consequence of the project (Johansson et al., 1989) was used to estimate expected value of $b$ :

$$
b=E\left\{b^{*}\right\}=\int_{-\infty}^{\infty}[1-G(b)] d b-\int_{-\infty}^{0} G(b) d b
$$

and the form selected for $G(b)$ was the logistic $G=\left[1+\mathrm{e}^{-\mathbf{x}^{\prime} \beta}\right]^{-1}$, where $\mathbf{x}$ is a vector that includes the amount $b$ and the vector $\mathbf{s}$, and $\beta$ is a vector of parameters to be estimated. 1992):

By solving ( 4 ), the expected value of WTP is obtained (COOPER \& LOOMIS,

$$
\bar{b}=-\frac{\beta_{0}^{*}}{\beta_{1}}
$$

where $\beta_{1}$ is the bid's parameter and $\beta_{0}^{*}=\beta_{0}$ is the constant of the model if no more variables are included or the value resulting from the constant added with the socioeconomic variables sample means multiplied by their respective coefficients.

In order to increase statistical efficiency (HANEMANN et al., 1991), it was adopted a follow up question to individuals interviewed. Thus, if the first response to an initial amount $b^{0}$ was "yes", she/he was asked to pay a higher value $b^{u}$, and if the first response was "no", the bid offered was a lower $b^{l}$. Thus the model delimited four intervals where $b^{*}$, the true individual WTP, can be (double bounded dichotomous choice model).

The $\operatorname{prob}\left\{b_{i}^{0} \leq b_{i}^{*}\right.$ and $\left.b_{i}^{u} \leq b_{i}^{*}\right\}$ of a double "yes" responses is

$$
\pi_{i}^{y y}=1-G_{i}^{u}
$$

where $G^{u}$ symbolizes the c.d.f. of upper bids given vector $\mathbf{s}$ and $y y$ stands for double-yes response. In the following equations, $G^{0}$ is the c.d.f. of initial bids, $G^{l}$ the c.d.f. for lower bids; nn: double-no response; yn: "yes" followed by "no"; ny: "no" followed by "yes". Thus probability of a no-no response is given by

$$
\pi_{i}^{n n}=G_{i}^{l}
$$


In analogous way, the other two alternatives are

$$
\pi_{i}^{n n}=G_{i}^{u}-G_{i}^{0} \text { and }
$$

$$
\pi_{i}^{n y}=G_{i}^{0}-G_{i}^{l}
$$

The $\hat{\beta}$ parameters were estimated by the maximum likelihood method. The non-linear procedure of Newton-Raphson's method was used to solve the problem of the logit (MADDALA, 1983; JUDGE et al., 1988; GREENE, 1997).

The null hypothesis for each parameter was tested by critical values of the $t$ distribution. Two measures were used to test the goodness of fit of the regression: the well-known likelihood ratio $(-2 \ln \lambda)$ and an adaptation on the correct prediction rate suggested by Judge et al. (1988) and Maddala (1988). They consider a correct case when an estimated probability over 0.5 is associated to an observed event in the same direction. This measure is applied to the single bounded dichotomous choice. The adaptation here suggested for the double bounded model is as follows: let $\hat{\pi}_{i}$ be the $1 \times 4$ vector with predicted probabilities for the $i$-th element of the sample and $\rho_{i}$ the respective $1 \mathrm{x} 4$ vector with coded responses ( 1 for observed response and 0 otherwise). The estimated probability is considered a correct prediction if

$$
\rho_{i}^{\prime} \hat{\pi}_{i}=\max \left(\hat{\pi}_{i}\right)
$$

where max means the largest value in the vector. The correct prediction rate is obtained by dividing the number of correct predictions by the total number of observations.

\section{Survey and results}

The variables included in the model were $x_{1}$ : bid amount (R\$ per month); $x_{2}$ : respondent sex (1: male, 0 : female); $x_{3}$ : age (years old); $x_{4}$ : education level in years of formal school ( 0 : without formal education; 1 : basic four-years cycle; 2 : elevenyears intermediate cycle; 3 : college education); $x_{5}$ : monthly per capita income (number of minimum wage, $\mathrm{R} \$ 136.00$ per month at the survey period.) and $x_{6}$ : main source of income (1: agriculture; 0: other).

The variables $x_{2}$ to $x_{4}$ above are the usually chosen in this type of survey. Sex may imply in a different perception by women and men towards environment effects on welfare. Education level perhaps results in high amount of information about environmental tasks. Higher age is to say more previously experienced governmental programs using public funds. Income is directly related to a new expenditure and bid amount. Source of income is a particular curiosity of the author about the influence on farmers toward the perspective of lose a part of their land for environment conservation or restoration with no looming 
economic benefits. It's reasonable to expect positive sign for $x_{1}$ (higher bid, lower WTP) and negative sign for $x_{5}$ (higher monthly income level, higher WTP). For the other variables included in the model aren't previous strong expectation but intuitive felling only.

The survey was carried out in 1999, from October to December, using the street-intercept method of interview. Eleven interviewers (four females and seven males) were recruited among senior undergraduate students of the College of Agriculture at the Universidade Federal de São Carlos (Sao Carlos Federal University), in Araras, state of São Paulo, Brazil. After students' training, the survey tools, text and visual (photo) aids as well as a questionnaire, were pre-tested in 171 interviews, and used to correct information to be presented, to improve questionnaire's design and to establish the vector of bids to be offered to respondents.

Just out curiosity, by the end of the survey, a local newspaper published an article warning people about "pseudo researchers" interviewing people on the streets, referring to this author's study. This happened despite the fact that the local authority in charge of urban water services was previously contacted by the author, informed about the survey to be undertaken and given a copy of the research proposal. Fortunately interviews thereafter were not affected by the incident.

People interviewed were informed about the environmental role played by riparian forests, legal concerns about conservation and preservation, social benefits arising from such project as well as its social costs, mainly represented by farmers' imminent lost income. The photo used as a visual aid showed a section of Corumbatai river with and without riparian forest, with and without crops, with low and high slopes. The payment vehicle chosen was an additional amount on the monthly households' water consumption bill, for the period of ten years, collected by local water supply agencies. The total amount collected would be transferred to local government, who would be in charge of the project. The quantity of supplied services to be attained by the project was established as "proportional to funds collected".

A random sample with 991 people was successfully interviewed from which 61 were excluded due to incomplete responses or to methodological concerns such as age below 20 years, residence outside the studied area, water consumed coming from other sources, consumers with stated no income and others, resulting in a net sample with 930 respondents (477 men and 453 women). The interviews were done in working days (during and after working hours), weekends and holidays. Around $15 \%$ of total accosted individuals refused to participate in the interview. Table 2 shows the bids offered, the correspondent sub-samples and the responses obtained were included in the study. 
514 - Valuing Riparian Forests Restoration:

a CVM Application in Corumbatai River Basin

Table 2. Bids offered and number of responses obtained.

\begin{tabular}{|c|c|c|c|c|c|c|c|c|c|}
\hline \multicolumn{3}{|c|}{ Bid (R\$ /month) } & \multirow{2}{*}{$\begin{array}{l}\text { Net sub- } \\
\text { samples }\end{array}$} & \multicolumn{2}{|c|}{$\mathbf{1}^{\text {st }}$ response } & \multicolumn{4}{|c|}{$1^{\text {st }}$ and $2^{\text {nd }}$ responses } \\
\hline Initial & Upper & Lower & & $Y$ & $N$ & $Y Y$ & $Y N$ & $N Y$ & NN \\
\hline 0.50 & 1.00 & 0.10 & 193 & 152 & 41 & 73 & 79 & 11 & 30 \\
\hline 2.00 & 3.00 & 1.00 & 189 & 100 & 89 & 24 & 76 & 29 & 60 \\
\hline 5.00 & 7.00 & 3.00 & 180 & 47 & 133 & 8 & 39 & 21 & 112 \\
\hline 10.00 & 15.00 & 7.00 & 196 & 25 & 171 & 0 & 25 & 4 & 167 \\
\hline 30.00 & 50.00 & 15.00 & 172 & 0 & 172 & 0 & 0 & 1 & 171 \\
\hline & Total & & 930 & 324 & 606 & 105 & 219 & 66 & 540 \\
\hline
\end{tabular}

Y: yes; N: no.

Source: survey data.

The reasons for "no-no" responses were asked and classified as shown in Table 3. The most interesting results were: a) the frequency distribution of the respondents who considered the bid "too high" had a reasonable pattern; b) a high number of no-no responses were based on "it's a government problem", "I don't trust government's use of funds" and "I' $m$ already paying a lot of taxes", all them typical protest responses; c) a small fraction of the respondents considered the farmers responsible for the problem, or short the time for a suitable response, or the possibility of being worse off with the project or declared the project not a relevant matter.

Table 3. Number of observations vs stated reasons for no-no responses.

\begin{tabular}{llcccccc}
\hline \multirow{2}{*}{ Reasons for "no-no" response } & \multicolumn{5}{c}{ Initial bid (R\$/month) } & \multirow{2}{*}{ Total } \\
\cline { 3 - 7 } & 0.50 & 2.00 & 5.00 & 10.00 & 30.00 & \\
\hline 1 & It's a value too high for me & 1 & 7 & 35 & 90 & 133 & 266 \\
2 & It's a government's problem, not mine & 5 & 14 & 17 & 12 & 15 & 63 \\
3 & It's a farmers' problem, not mine & 0 & 3 & 3 & 5 & 4 & 15 \\
4 & I don't trust government's use of funds & 13 & 14 & 28 & 37 & 19 & 111 \\
5 & I don't think this is an important matter & 0 & 1 & 4 & 4 & 3 & 12 \\
6 & I need more time to think about it & 0 & 2 & 6 & 3 & 2 & 13 \\
7 & I will be worse off with the project & 2 & 2 & 2 & 4 & 2 & 12 \\
8 & I'm already paying a lot of taxes & 12 & 21 & 35 & 44 & 30 & 142 \\
9 & Other & 1 & 4 & 4 & 2 & 3 & 14 \\
\hline
\end{tabular}

Obs.: Sums cannot be compared with data from Table 2 because more than one "reason" were allowed for each respondent.

Source: survey data. 
The higher number of "no-no" responses at least for some reasons declared may be derived from the socioeconomic conditions in the region. Around 57\% of the sampled people receive less than two minimum wages per capita per month. Less than $2 \%$ asserted a monthly income upper 10 minimum wages per capita. People with a very low income have a few chance for savings or new expenditures without reducing their actual low welfare level. In another way, remembering that the people allowed in the net sample were 20 years old at minimum, a expressive share received a not suitable education: 4,1\% with no formal education (zero years) and $40,5 \%$ at the four-years basic cycle level. Only $12,4 \%$ declared their formal education at the college level, including uncompleted courses (???). In despite this scenario, the facts described are better than other Brazilian regions.

The results of the double bounded dichotomous choice logit model showed high significance and the expected positive sign for the bid amount coefficient, which means that an increase in the bid value causes a decrease in expected probability of the willingness to pay that value. It also shows significance level at 0.05 and the expected negative sign for the income coefficient (Table 4).

Table 4. Double bounded logit model estimates.

\begin{tabular}{llcccc}
\hline $\mathbf{j}$ & \multicolumn{1}{c}{ Variable } & $\hat{\beta}_{j}$ & $\hat{\sigma}_{j}$ & Wald $\chi^{2}$ & Signif \\
\hline 0 & Constant & $-2,1612$ & 0,3709 & 33,9451 & $* *$ \\
1 & Bid amount & 0,5821 & 0,0287 & 411,9735 & $* *$ \\
2 & Respondent sex & $-0,0360$ & 0,1514 & 0,0567 & $\mathrm{~ns}$ \\
3 & Age & 0,0231 & 0,0057 & 16,3185 & $* *$ \\
4 & Education level & 0,1328 & 0,1256 & 1,1189 & $\mathrm{~ns}$ \\
5 & Monthly per capita income & $-0,0912$ & 0,0361 & 6,3698 & $*$ \\
6 & Main source of income & $-0,1176$ & 0,4207 & 0,0782 & $\mathrm{~ns}$ \\
\hline
\end{tabular}

NB.: ** significant at $0.01 ;{ }^{*}$ significant at $0.05 ; n s$ : not significant at 0.10 .

The null hypothesis for regression tested by the likelihood ratio must be rejected at 0.01 level of significance. The adjusted model correctly predicted $61 \%$ of expected probabilities. The mean WTP was equal to R $\$ 2.60$ per month which is equivalent to approximately $R \$ 274,000$ per month (at last 1999 quarter' prices) when accounting for about 133,000 residences in the studied area. The double bounded logit model was more efficient than the single bounded model as stated by Hannemann et al. (1991).

Passing over the constant, respondent sex coefficient was not significant at 0.10 level, with negative sign (women trend to refuse WTP). The age coefficient, at high significance level, shows negative sign, perhaps denoting that more 
516 - Valuing Riparian Forests Restoration:

a CVM Application in Corumbatai River Basin

experienced governmental programs result in a more skeptic people behavior. Education level was not significant at 0.10 level, with a slightly surprising positive sign, is to say, greater school level, smaller WTP, not allowing any consistent speculation. Overlooking the fact that main source of income was not significant at 0.10 level, it shows a interesting negative sign, meaning that income attached to agriculture not implies in people involved trend to reject to pay some amount for the project.

In spite of thousands of references on CVM applications referring to many subjects, a very little number were found in the literature about the specific stated subject "riparian forests restoration". By comparing the average monthly WTP equal to $R \$ 2,60$ found in this survey, some results obtained by other authors are quoted forthwith (Table 5).

Table 5. Some results obtained by other authors for average monthly WTP for riparian forests restoration or preservation.

\begin{tabular}{lccl}
\hline \multicolumn{1}{c}{ Author } & Year & Mean WTP & \multicolumn{1}{c}{ Place } \\
\hline Gonzáles-Cabán \& Loomis & 1997 & US\$ 1.75 & Mameyes river, Puerto Rico \\
Ribeiro & 1999 & R\$ 14. 57 & Meia Ponte river, GO, BR \\
Silva & 2004 & R\$ 10.40 & Colônia river, BA, BR \\
Mattos & 2006 & R\$ 27.98 & Viçosa, MG, BR \\
Cunha & 2008 & R\$ 6.16 & Mogi-Pardo river basin, SP, BR \\
Tôsto & 2010 & R \$ 6.58 & Araras, SP, BR \\
\hline
\end{tabular}

Due to the well-known asymmetry of income distribution, a new model was estimated where the income variable was measured in its logarithm. This procedure increased the level of significance of the income coefficient from 0.05 to 0.01 . Other coefficients' level of significance, the expected WTP and the correct prediction rate showed no change as compared to the former model.

The exclusion of protest bids (183) from the sample resulted in an expected higher mean WTP (R\$ 2.63 per month), a 0.56 correct prediction rate and no changes in parameters' significance levels.

Using only the first yes-no response (single bounded model) resulted in $\mathrm{R} \$ 3.04$ mean WTP for the whole sample, with a 0.78 correct prediction rate and no changes in significance levels; for the sample excluding protest bids, the mean WTP went up to $R \$ 4.32$, correct prediction rate at 0.79 and no changes in parameters' significance levels. As in other studies, the double bounded model led to lower WTP estimates. 


\section{Final comments}

The street-intercept interview technique was a satisfactory option chosen to carry out the CVM application here proposed, except for the weekday and time chosen for the interviews. It seems that interviews on weekends or after work hours should be given preference since people are under less pressure from domestic and professional tasks, although some risk of sample misrepresentation could be introduced.

The percentage of individuals in the sample who were not willing to pay any value for the increase in the riparian forest areas in the studied basin was very high $(58 \%)$. Close to one sixth of total sample said they were not willing to pay even the derisive lowest bid of $\mathrm{R} \$ 0.10$ per month.

It is suggested that in future studies of this nature, in countries where CVM applications are practically unknown, researchers and local authorities should previously interact with each other at the institutional level in order to avoid incidents which might affect research results.

These results show how important CVM can be as a decision-aid to policymakers in Brazil. However further studies are needed, particularly at this time when important policy decisions regarding water quality improvement and other environmental problems are about to be made by government agencies which will affect the studied area as well as other areas in the country. The "farmers side" of this problem is another focus or desirable urgent studies.

The applicable methodology is well-known in international literature, thousands of studies have been published based on CVM but only a few is done by Brazilian researchers mainly with academic purposes. It's hopefully that this study can add some knowledge on the subject and instigate further research on the focal theme and related to it mainly in view the increasing enforcement do by the Brazilian Public Ministry on environmental concerns and the growing public demand for higher environmental quality and universal claim for sustainability. The preservation or restoration of riparian forests is one of the most important actions to satisfy this demand. For satisfy demand by consumption of goods it's necessary to pay for them but for environmental services the question arises: how much?

CVM alone can't solve the whole task but is an important tool which joined to human knowledge areas into Ecological Economics and others can elicit a reasonable accuracy for the value of environmental services with no formal market as done, for example, by Tôsto (2010) who valued riparian forest restoration by CVM and carbon holding, soil erosion and adequacy of land use by farmers using another methods, in Araras, Brazil. 
518 - Valuing Riparian Forests Restoration:

a CVM Application in Corumbatai River Basin

\section{References}

BISHOP, R.C.; HEBERLEIN, T.A., 1979. Measuring values of extramarket goods: are indirect measures biased? American Journal of Agricultural Economics, 5:926930.

BRASIL, 1965. Código Florestal. Lei No. 4.771.

BRASIL, 1989. Lei No. 7.754.

BROMLEY, D.W., 1996. The environmental implications of agriculture. Staff Paper Series No. 401, University of Wisconsin., Madison.

BROWN, T.C., 1994. Experiments on the difference between willingness to pay and willingness to accept: comments. Land Economics, 4:520-522.

BROWN, T.C.; GREGORY, R., 1999. Why the WTA-WTP disparity matters. Ecological Economics, 3:323-325

COOPER, J.; LOOMIS, J., 1992. Sensitivity of willingness-to-pay estimates to bid design in dichotomous choice contingent valuation models. Land Economics, 2:211-224.

CUMMINGS, R.G.; BROOKSHIRE, D.S.; SCHULZE, W.D., 1986. Valuing environmental goods: an assessment of the contingent valuation method. Rowman and Allanhead, New Jersey, 269 pp.

CUNHA, F. L. S. J. Valoração dos serviços ecossistêmicos em bacias hidrográficas. Campinas, 2008. Tese (Doutorado) - Instituto de Economia. Unicamp (Universidade Estadual de Campinas).

FREEMAN, A.M. III, 1979. Approaches to measuring public goods demands. American Journal of Agricultural Economics, 5:915-920.

GONZÁLEZ-CABÁN, A.; LOOMIS, J. Economic benefits of maintaining ecological integrity of Río Mameyes, in Puerto Rico. Ecological Economics, v.21, n.1, p.63-75, April 1997.

GREENE, W.H., 1997. Econometric analysis. 3.ed. Prentice-Hall, New Jersey, 1075 pp.

HANEMANN, W.; LOOMIS, J.; KANNINEN, B., 1991. Estimation efficiency of double-bounded dichotomous choice contingent valuation. American Journal of Agricultural Economics, 4:1255-1263.

HANEMANN, W.M., 1984. Welfare evaluation in contingent valuation experiments with discrete responses. American Journal of Agricultural Economics, 3:.332-341.

HANEMANN, W.M., 1989. Welfare evaluations in contingent valuation experiments with discrete response data: reply. American Journal of Agricultural Economics, 4:1057-1061. 
HANEMANN, W.M., 1991. Willingness to pay and willingness to accept: how much can they differ? American Economic Review, 3: 635-647.

JOHANSSON, P.-O.; KRISTRÖM, B.; MÄLER, K.G., 1989. Welfare evaluations in contingent valuation experiments with discrete response data: comment. American Journal of Agricultural Economics, 4:1054-1056.

JUDGE, G.C.; HILL, R.C.; GRIFFITHS, W.E.; LÜTKPOLHL, H.; LEE, T.-C., 1988. Introduction to the theory and practice of econometrics. 2.ed. John Wiley \& Sons, New York, 1024 pp.

KOFFLER, N.F., 1993. Uso das terras do rio Corumbatai em 1990. Geografia, 1:135150.

MADDALA, G.S., 1983. Limited-dependent and qualitative variables in econometrics. Cambridge University Press, Cambridge, $401 \mathrm{pp}$.

MADDALA, G.S., 1988. Introduction to econometrics. Macmillan, New York, 472 pp.

MATTOS, A. D. M. Valoração ambiental de áreas de preservação permanente da microbacia do ribeirão São Bartolomeu no município de Viçosa, MG. Viçosa, 2006. Dissertação (Mestrado) - Universidade Federal de Viçosa.

MITCHELL, R.C.; CARSON, R.T., 1989. Using surveys to value public goods: the contingent valuation method. Resources for the Future, Washington DC, 463 pp.

NASSIF, A.M.A.; VIANA, V.M., 1998. Melhoria do sistema de produção de água pelo SEMAE através de atividades de recuperação e conservação florestal. In: SEMINÁRIO DE RECUPERAÇÃO FLORESTAL E DESENVOLVIMENTO SUSTENTÁVEL NA BACIA DO RIO CORUMBATAÍ, 2. SEDEMA, Piracicaba, p.40-42.

PEARCE, D.W.; TURNER, R.K., 1989. Economics of natural resources and the environment. Johns Hopkins, Baltimore, 377 pp.

PINO, F.A. et al (Org.), 1997. Levantamento censitário de unidades de produção agrícola do Estado de São Paulo. IEA: CATI: SAA, São Paulo, 4v.

RANDALL, A., 1987. Resource economics: an economic approach to natural resource and environmental policy. 2. ed. John Wiley \& Sons, New York, 434 pp.

RANDALL, A., 1997. The NOAA panel report: a new beginning or the end of an era? American Journal of Agricultural Economics, 5:1489-1494.

RANDALL, A.; STOLL, J.R., 1980. Consumer's surplus in commodity space. American Economic Review, 3:449-455. 
RIBEIRO, F.L. Avaliação contingente de danos ambientais: o caso do rio MeiaPonte em Goiânia-GO. Viçosa, 1998. 80p. Tese (Mestrado) - Universidade Federal de Viçosa.

SAMUELSON, P.A., 1954. The pure theory of public expenditure. Review of Economics and Statistics, 4:387-389.

SEADE-State Data Analysis System Foundation. São Paulo State Municipality Information. http://www.seade.gov.br (13/08/1999).

SILVA, A. M. Valoração econômica de matas ciliares na microbacia do rio Colônia, sudeste da Bahia. Ilhéus, 2004. Dissertação (Mestrado) - Universidade Estadual de Santa Cruz.

TOSTO, S. G. Sustentabilidade e Valoração de Serviços Ecossistêmicos no Espaço Rural do Município de Araras, SP Campinas, 2010. Tese (Doutorado) - Instituto de Economia. Unicamp (Universidade Estadual de Campinas).

WILLIG, R.D., 1976. Consumer's surplus without apology. American Economic Review, 4:589-597. 